\title{
Uusioersily
}

\section{Accommodative function in individuals with Autism Spectrum Disorder}

Anketell, P., Saunders, K. J., Gallagher, S., Bailey, C., \& Little, J-A. (2018). Accommodative function in individuals with Autism Spectrum Disorder. Optometry and Vision Science, 95(3), 193-201.

https://doi.org/10.1097/OPX.0000000000001190

Link to publication record in Ulster University Research Portal

\section{Published in:}

Optometry and Vision Science

Publication Status:

Published (in print/issue): 01/03/2018

DOI:

10.1097/OPX.0000000000001190

\section{Document Version}

Author Accepted version

\section{General rights}

Copyright for the publications made accessible via Ulster University's Research Portal is retained by the author(s) and / or other copyright owners and it is a condition of accessing these publications that users recognise and abide by the legal requirements associated with these rights.

\section{Take down policy}

The Research Portal is Ulster University's institutional repository that provides access to Ulster's research outputs. Every effort has been made to ensure that content in the Research Portal does not infringe any person's rights, or applicable UK laws. If you discover content in the Research Portal that you believe breaches copyright or violates any law, please contact pure-support@ulster.ac.uk. 
Title: Accommodative function in individuals with Autism Spectrum Disorder

Authors:

Dr Pamela M Anketell, $\mathrm{PhD}^{1}$

Professor Kathryn J Saunders PhD FCOptom²

Dr Stephen M Gallagher $\mathrm{PhD}^{3}$

Dr Clare Bailey ${ }^{4}$

Dr Julie-Anne Little $\mathrm{PhD}^{2}$

1. Orthoptic Department, Belfast Health \& Social Care Trust, Royal Victoria Hospital, Grosvenor Road, Belfast, United Kingdom BT12 6BA

2. Optometry \& Vision Science Research Group, Biomedical Sciences Research Institute, Ulster University, Cromore Road, Coleraine, United Kingdom BT52 1SA

3. School of Psychology, Ulster University, Cromore Road, Coleraine, United Kingdom BT52 1SA

4. Department of Paediatrics, Northern Health \& Social Care Trust, Bush Road, Antrim, Northern Ireland, United Kingdom BT41 2RL

Corresponding author: Dr Julie-Anne Little

Senior Lecturer, Optometry \& Vision Science Research Group, Biomedical Sciences Research Institute, Ulster University, Cromore Road, Coleraine, United Kingdom BT52 1SA Ja.little@ulster.ac.uk

+44(0) 2870124374

Tables: 3

Figures: 3

Revision Submission date: $26^{\text {th }}$ October 2017

Manuscript Title: Accommodative function in individuals with Autism Spectrum Disorder Short title: Accommodative dysfunction in ASD 
Significance (50 Words): This study investigated accommodative function in 124 children with autism spectrum disorder (ASD), in conjunction with other vision measures with habitual refractive corrections. Accommodative responses were significantly poorer in individuals with ASD compared with age-matched typically developing controls, and hypoaccommodation was associated with reduced near visual acuity and convergence.

\section{Abstract}

Purpose

Autism Spectrum Disorder (ASD) is a neurodevelopmental disorder with a reported prevalence of $1.1-1.5 \%$. Accommodative dysfunction has been noted in other developmental conditions including cerebral palsy and Down's syndrome. The aim of this study was to investigate how accommodative accuracy and near visual function in ASD compared to typically developing controls.

\section{Methods}

Accommodative accuracy was assessed using modified Nott dynamic retinoscopy. Individual accommodative demand and response was calculated incorporating residual refractive error (difference between cycloplegic and habitual refractive state). Near visual measures included; near visual acuity (NVA), near point of convergence, fusional reserves and stereoacuity. Cycloplegic autorefraction confirmed refractive error.

Results

Accommodative responses were measured from 124 participants with ASD (6-17 years) and 204 age-matched controls. There was no significant difference in the magnitude of residual refractive error between groups $(\mathrm{p}=0.10)$. The prevalence of a clinically significant lag of accommodation was greater in the ASD group compared to controls (ASD $=17.4 \%$, controls $=4.9 \%, \chi^{2}=13.04, p<0.0001$ ). NVA was significantly reduced in the ASD group with a clinically significant lag of accommodation $(p<0.01)$. A few participants $(\mathrm{n}=24$ controls, $\mathrm{n}=14$ ASD) had un- or under-corrected refractive errors (SER $>/=+2.00 \mathrm{D},>1.00 \mathrm{DC}$ ), and when these were removed from analysis, there was still an increased prevalence of hypoaccommodation in ASD (14.7\%).

\section{Conclusion}


Children with ASD were significantly more likely to have accommodative deficits (and associated near visual deficits) in their presenting refractive state than typically developing children. Appraisal of refractive error, accommodation and near visual acuity should be considered in visual assessment of children with ASD.

Key words: Autism spectrum disorder, autism, Asperger's syndrome, accommodation, refractive error, near vision, near visual acuity

Autism spectrum disorder is a neurodevelopmental disorder characterised by impairment of social interaction, communication, and/or repetitive behaviours or routines. ${ }^{1,2}$ The term autism spectrum disorder includes individuals with a diagnosis of autism and Asperger's syndrome. In the United Kingdom the reported prevalence of autism spectrum disorder is approximately $1.1 \%{ }^{3}$ while in the United States of America the prevalence is reported to be $1.46 \%{ }^{4}$

In an effort to develop an improved understanding of autism spectrum disorder many areas of visual processing have previously been investigated. These include: the development of motion perception, ${ }^{5}$ investigation of eye movements, ${ }^{6,7}$ psychophysical tasks such as embedded figure detection ${ }^{6}$ and other psychophysical measures of vision.,10 However, previous literature describing clinical measures of vision has been limited by restricted participant selection (clinical samples recruited from ophthalmology or optometry services), small sample sizes or retrospective review of clinical records. ${ }^{11-13}$ More recently measures of visual acuity have been reported from larger populations of individuals with autism spectrum disorder recruited through paediatric registers, special education schools and/or resource centres. ${ }^{14,15}$ To our knowledge measures of accommodative performance in individuals with autism spectrum disorder have not been reported. This is important as accurate accommodation is necessary for effective near vision and normal ocular development, and any deficits in near vision will impact learning. ${ }^{16}$ Clear near vision is required to effectively 
access detailed near visual tasks including educational material, toys and recreational tasks. As a communication tool, picture schedules are also commonly used for individuals with autism spectrum disorder. Accommodative dysfunction has previously been reported in individuals with neurodevelopmental disability. For example, Woodhouse et al. ${ }^{17}$ noted that up to $80 \%$ of children with Down syndrome have poor accommodation. Deficits in accommodation have also been reported in over $55 \%$ of children with cerebral palsy. ${ }^{18}$

Milne et al. ${ }^{14}$ examined Near Point of Convergence in 51 children with autism spectrum disorder and reported that near point of convergence was significantly reduced (median 8.5cm (Inter-quartile range 6-12cm)) compared to typically developing individuals. They also reported reduced base-in near fusion range, but did not find any between group differences in stereoacuity scores. However, they did not report measures of accommodative function to investigate whether reduced convergence was associated with reduced accommodation.

Objective assessment of accommodative responses using the modified Nott dynamic retinoscopy procedure has been established as a repeatable and quick technique. ${ }^{19-21}$ The technique is also widely used to assess accommodative function in individuals with developmental delay. ${ }^{17,18,22}$ Normative data for typically developing children have been described by McClelland and Saunders. ${ }^{23}$ They reported mean and 95\% confidence intervals for 4, 6 and 10 dioptre accommodative demands for 125 typically developing children between the ages of 4 and 15 years. For each of these three demands the mean lag \pm standard deviation and confidence intervals for each demand were; 4D demand mean 0.30 $\pm 0.39 \mathrm{D}$, confidence intervals 2.94 to $4.46 \mathrm{D}, 6 \mathrm{D}$ demand $0.74 \pm 0.58 \mathrm{D}$, confidence intervals 4.12 to 6.40 and $10 \mathrm{D}$ demand $2.50 \pm 1.27 \mathrm{D}$, confidence intervals 5.02 to $10.00 \mathrm{D} .^{23}$

The aim of the present study was to assess accommodative accuracy and near visual functions in a population of children with autism spectrum disorder compared to a control group of typically developing children. 


\section{Methods}

Ethical approval was received from the Ulster University Research Ethics Committee and the Office for Research Ethics Committees for Northern Ireland to invite participants to the study. Parents of participants provided written informed consent. At the time of assessment verbal assent was requested by the examiner where possible. The research adhered to the tenets of the Declaration of Helsinki.

The Child Health System is a patient record system. This system is used to record information of all health screening, immunisations and medical diagnoses on every child in Northern Ireland, United Kingdom. Following review by a multi-disciplinary autism spectrum disorder diagnostic service, children diagnosed with autism or Asperger's Syndrome have this recorded on their Child Health System record. Children with a diagnosis of autism spectrum disorder were recruited through the Child Health System of two Health and Social Care Trust areas in Northern Ireland. To ensure a broad spectrum of abilities in the participating children additional study information was also disseminated to families through special education schools in Northern Ireland. A total of 128 children with a diagnosis of autism spectrum disorder (autism n=88, Asperger's n=40) were recruited, with a mean age of 10.9 $\pm 3.3 y e a r s$ (range 6.2 to 16.9 years). This is reflective of the frequency of sub-type diagnosis. Participants with autism spectrum disorder were also categorised depending on the level of educational support received. There were three levels: (i) 33 children attending mainstream education without educational support, i.e. no statement of educational needs, (ii) 42 children attending mainstream education with educational support and (iii) 53 children attending special schools.

Typically developing children were recruited through six mainstream schools including four primary (age 5-11 years) and two post-primary (11-18 years) schools to act as a control 
group. A total of 206 participants (Caucasian $n=204$ ) were recruited with a mean age of 11.5 \pm 3.1 years (range 6.4 to 16.5 years).

All visual measures were assessed with participants wearing their habitual refractive error and focimetry was conducted on these spectacles.

An objective measure of accommodative accuracy was assessed using the modified Nott dynamic retinoscopy technique. The same examiner (Anketell) undertook all measures of accommodation. The Ulster-Cardiff Accommodation Cube, (UC-cube), (PA Vision Ltd, Kent, United Kingdom) was used as a fixation target (Figure 1). The participant was asked to fixate the internally illuminated Perspex cube measuring $4.4 \times 4.4 \times 4.4 \mathrm{~cm}$. Each face on the UC-cube is designed to be of interest to children and questions were asked to encourage fixation on the target. The target was placed at $25 \mathrm{~cm}$ (4D demand), as this is reported as a typical reading distance used by children, ${ }^{24}$ for the duration of the assessment.

\section{Figure 1 about here}

The rule of the UC-cube rested against the participant's chin. The examiner placed the retinoscope level with the target and assessed the retinoscopy reflex. If a 'neutral' reflex is seen no lag or lead is present. If an 'against' movement is identified the examiner moves the retinoscope forward until a neutral movement is identified. This indicates that the participant is over-accommodating and is called a 'lead' of accommodation. The size of the accommodative 'lead' is determined by the dioptric difference between the stimulus position and the position of the retinoscope when the neutral reflex is seen. Conversely, if a 'with' movement is identified the participant is under-accommodating with reference to the stimulus and the retinoscope must be moved away from the participant's eye to achieve neutral. The accommodative 'lag' in this case is the dioptric difference between the stimulus position and the position at which neutrality is achieved by the retinoscopist. The least hyperopic meridian was identified in all cases and this meridian was used to assess the lag/lead of each 
participant's response. Once a neutral reflex is observed the examiner marks the position of the neutral reflex, the distance from the cornea to the mark is recorded and the presence of a lead (against movement) or a lag (with movement) is calculated.

Accommodative demand will differ according to the residual refractive error difference between the participant's habitual refractive correction (if they wore any spectacles) and that found with cycloplegic refraction. Therefore individual accommodative demands were calculated using the following formula:

Accommodative demand $=\left(\operatorname{LHM}_{(\text {cyclo })}-\operatorname{LHM}_{(\text {habitual })}\right)+$ target distance dioptric demand,

where LHM denotes the least hyperopic meridian of the refractive error.

Accommodative demand is the total amount of accommodation required to focus a near target at $25 \mathrm{~cm}$, (4D), plus any residual or uncorrected refractive error i.e. if the participant has an uncorrected hyperopic refractive error of $+1.5 \mathrm{D}$ the total accommodative demand for the individual would be 5.5D. Accommodative response is the actual accommodative response to the target demands i.e. the measured response plus any uncorrected refractive error at the least hypermetropic meridian. ${ }^{25}$ Accordingly, if the dioptric position of neutrality was determined at 3D $(33 \mathrm{~cm})$, and if the same residual refractive error of +1.50 was used as in the example above, their accommodative response would be 4.5D. Accommodative responses for each individual were calculated using the following formula:

Accommodative response $=$ Dioptric position of neutral reflex response $+\left(\operatorname{LHM}_{(\mathrm{cyclo})}-\operatorname{LHM}_{(\text {habitual })}\right)$,

Participants were assessed wearing their habitual refractive correction and subsequent cycloplegic autorefraction was used to calculate the individual accommodative demand and accommodative response.

Alongside measures of accommodative response, near visual acuity, near point of convergence, fusional reserves, stereoacuity scores and ocular posture were assessed. These assessments were performed with participants wearing their habitual refractive correction if 
they had one. Near visual acuity was assessed monocularly using the Massachusetts Near Vision Screener (Goodlite, USA) that assesses near visual acuity between 1.0 and -0.3 logMAR. Participants named or matched letters using a matching card. Near point of convergence was assessed using the Royal Air Force Near Point Rule (Haag Streit, Essex, United Kingdom). The breakpoint was recorded (in centimetres) as the point that the participant subjectively reported diplopia or in the case of non-verbal participants the point at which convergence was noted to break by the examiner. The process was repeated three times and a mean near point of convergence calculated. Fusional reserves were assessed using a prism bar to introduce base in and base out prism to elucidate break point. For those unable to communicate the presence of diplopia an objective assessment of break point was made by the examiner (Anketell). A single measure of fusional reserves using a near fixation target was recorded for base out and base in prism. Threshold stereoacuity scores were recorded using the near Frisby stereotest as described in previous work from our research group. ${ }^{26}$ In brief, participants were initially asked to identify the target on the $6 \mathrm{~mm}$ plate at a distance of $80 \mathrm{~cm}$. Two of three presentations were required to record a positive response. If the target was correctly identified the process was repeated using the $3 \mathrm{~mm}$ plate and then the $1.5 \mathrm{~mm}$ plate. If all presentations at $80 \mathrm{~cm}$ were correct the test distance was increased to $150 \mathrm{~cm}$ and the process repeated using the $3 \mathrm{~mm}$ and $1.5 \mathrm{~mm}$ plates. If the target was not identified using the $6 \mathrm{~mm}$ plate at $80 \mathrm{~cm}$ the test distance was reduced in $10 \mathrm{~cm}$ increments. If the target was not identified at $30 \mathrm{~cm}$ using the $6 \mathrm{~mm}$ plate a fail was recorded. Those participants with a stereoacuity score of greater than 85 seconds of arc were recorded as failing the test based on typically developing normative scores for crossed stereoacuity recorded using the Frisby stereotest. ${ }^{26}$ Ocular posture was assessed using a conventional cover test technique for both near and distance fixation.

After all other measures were taken, cycloplegic assessment of refractive error was conducted. Refractive error was measured using the Shin Nippon NVision-K 5001 open-field 
autorefractor following instillation of one drop of cyclopentolate hydrochloride $1 \% .{ }^{27}$ Thirty minutes after the instillation of cyclopentolate, pupil dilation size, lack of light response and symmetry was checked for efficacy of drug action, and autorefraction was conducted if satisfactory. Five successive readings were taken and the instrument average outcome refractive error was used for analyses.

Statistical analyses and graphical presentation were conducted using Intercooled Stata 11 (http://www.stata.com/company/). Descriptive statistics are presented as median and interquartile range as refractive and accommodative data were not normally distributed. Nonparametric statistics used were Wilcoxon rank-sum tests (Mann-Whitney tests) and Wilcoxon matched pairs signed rank test. Linear regression analysis analysed individual accommodative demand versus response between groups, and Fisher's transformation and t distribution were used to compare correlations and slopes. Statistical significance was set at $5 \%$.

\section{Results}

Accommodative responses were successfully measured from 124 participants with autism spectrum disorder and 204 control participants. There was no significant difference in right and left eye accommodative lag data therefore right eye data are presented (Wilcoxon matched pairs signed rank test $(\mathrm{z})$; autism spectrum disorder group $\mathrm{z}=1.16, p=0.25$, control group $\mathrm{z}=1.46, p=0.15)$.

Cycloplegic refractive error data were not available for a small number of participants (autism spectrum disorder $n=15$, control $n=2$ ), therefore data for these individuals were excluded from further analyses. A detailed analysis of profile of refractive error in autism spectrum disorder in this study population has been reported elsewhere. ${ }^{28}$ In brief, Table 1 presents a summary of the median sphere, cylinder, and mean spherical equivalent 
cycloplegic refractive error data for both groups. Figure 2 is a scatterplot comparing the difference between cycloplegic refractive error and habitual spectacle prescriptions (both spherical equivalent), with Pearson's correlation $r=0.85$ for the autism spectrum disorder data and $\mathrm{r}=0.80$ for controls. There was no significant difference between the correlation values (Fisher's $\mathrm{z}=1.43, \mathrm{p}=0.15)$ nor the slopes of the linear regression lines $(\mathrm{t}=0.89, \mathrm{p}=0.37)$. Habitual refractive correction was worn by 42 control (21\%) and 30 autism spectrum disorder (24\%) participants. The median sphere was; control 0.00D (IQR-1.00 to +1.00D); autism spectrum disorder +0.25D (IQR -1.50 to $+2.00 \mathrm{D}$ ) while median cylinder was; control 0.25DC (IQR -0.50 to 0.00DC); autism spectrum disorder -0.63DC (IQR -2.00 to 0.00DC). The median (inter-quartile range) difference between cycloplegic refractive error spherical equivalent and habitual spectacles spherical equivalent (where no habitual spectacle prescription was defined as $0.00 \mathrm{D})$ was $0.875 \mathrm{D}(0.50-1.375)$ for the autism spectrum disorder group, and this was slightly less than the median difference for controls, which was $1.00 \mathrm{D}$ (0.50-1.625). However, there was no significant difference in the magnitude of residual refractive error by spherical equivalent between groups (Mann-Whitney, z=1.64, p=0.10).

\section{Table 1 about here}

\section{Figure 2 about here}

Table 2 provides descriptive statistics and between-group comparison of accommodative lag, accommodative response and accommodative demand for the autism spectrum disorder and control groups. Median accommodative lag, response and demand were significantly different in the autism spectrum disorder group compared to the control group (MannWhitney, all $\mathrm{p}<0.02)$.

\section{Table 2 about here}

Within the autism spectrum disorder group, there was no significant difference in accommodative lag, response or demand between the diagnostic sub-groups 
(autism/Asperger's $p>0.32)$ or education categories $(p>0.07)$. Retrospective power calculation with sample size indicated that the difference detected in accommodative lag had a power of $99 \%$ overall between groups, and a power of $83 \%$ for autism spectrum disorder sub-groups by educational classification.

Figure 3 plots the individual actual accommodative demand against the accommodative response for the autism spectrum disorder and control groups. Normative data from McClelland and Saunders ${ }^{23}$ have identified that a clinically significant lag of accommodation in typically developing children is a lag of $1.08 \mathrm{D}$ or larger for a target placed at $25 \mathrm{~cm}$ (4D demand). This level is indicated on Figure 3. Individual data points falling below this line, indicating clinically significant lags, were counted for each group. This indicated that a clinically significant lag of accommodation was found in 18.4\% $(n=20 / 109 z 0 z)$ and $4.9 \%$ ( $n=10 / 202109$ ) of the autism spectrum disorder and control groups respectively. This lag classification is significantly more common in the autism spectrum disorder group (MannWhitney, $\mathrm{z}=-3.8, p<0.0001)$. Linear regression analyses for the autism spectrum disorder and control group were; autism spectrum disorder $\mathrm{F}_{(1,107)}=242.64, p<0.0001, \mathrm{y}=0.29+0.82 \mathrm{x}$, $\mathrm{R}^{2}=0.69$, control; $\mathrm{F}_{(1,200)}=665.01, \quad p<0.0001, \mathrm{y}=-0.17+0.97 \mathrm{x}, \mathrm{R}^{2}=0.77$. There was no significant difference between the correlation values (Fisher's $\mathrm{z}=-1.36, \mathrm{p}=0.17$ ), but the slope of the linear regression line was significantly steeper for the control group data $(\mathrm{t}=2.28$, $\mathrm{p}=0.02$ ), indicating less accommodative response change was exhibited by the autism spectrum disorder group per unit of demand relative to the control group. However, a number of participants in both groups had significant uncorrected refractive error. A significant refractive error was conservatively defined as a $>/=2.00 \mathrm{D}$ spherical equivalent difference between cycloplegic and habitual refractive correction, based on repeatability of refractive error measurement, ${ }^{29}$ consideration of prescribing guidance, ${ }^{30}$ and in the context of previous studies' use of a +2.00D cut-off to define hyperopia. ${ }^{\text {e.g.27 }}$ Data identifying that (at least) this level of hyperopia begins to impact on accommodative performance were also considered. ${ }^{31}$ 
By this definition, 24 control participants (11.9\%) and 14 autism spectrum disorder participants (14.7\%) had significant uncorrected refractive error. When these subjects were removed from analysis there remains significantly more participants with autism spectrum disorder with an accommodative lag than controls (Mann-Whitney, $\mathrm{z}=-2.74, p=0.006$; autism spectrum disorder $14.7 \% n=14 / 95$, controls $5.1 \% n=9 / 178$ ). Within the autism spectrum disorder group, there was no significant difference in the prevalence of participants classified as having a lag of accommodation when analysed by diagnostic sub-groups or education categories (Mann-Whitney, $p>0.05$ for both analyses).

\section{Figure 3 about here}

A number of participants with autism spectrum disorder were using medications that may possibly affect accommodative responses $(n=24)$. Exclusion of these participants from the data did not alter findings of a significant increase in the prevalence of a clinically significant accommodative lag in autism spectrum disorder compared to the control group $(p<0.01)$.

Within-group analysis: near point of convergence, near visual acuity, spherical equivalent refractive error, astigmatism, fusional reserves and those with reduced stereoacuity are reported in Table 3 for both the autism spectrum disorder and control groups. Manifest strabismus was present for eight participants with autism spectrum disorder and three typically developing participants, and data were excluded from these individuals for analysis of binocular functions near point of convergence, fusional reserves, and stereoacuity. Table 3 also describes the outcomes of these measures for the autism spectrum disorder and control groups and for those with and without a clinically significant lag of accommodation, noting the presence of any significant difference between those with and without a clinically significant lag of accommodation. Near visual acuity was significantly reduced in the autism spectrum disorder group for those with a lag of accommodation, and this remained when those with residual refractive errors $(>/=2.00 \mathrm{D})$ and un- or under-corrected astigmatism (>1.00DC) were excluded from analysis (Mann-Whitney, $p=0.03$ ). NPC was also 
significantly poorer in the autism spectrum disorder group, though when participants with both residual refractive error and astigmatism were excluded this dropped out of significance (Mann-Whitney, $p=0.12$ ).

Between-group analysis: Table 3 describes the analysis between group data. Of note there was significantly reduced near point of convergence and significantly more participants failing the Frisby stereotest in the autism spectrum disorder group compared to the control group when the complete data set were analysed (Mann-Whitney, $p<0.01$ for both analyses). When data were excluded from those with residual refractive errors and un- or undercorrected astigmatism this remained significant for NPC (Mann-Whitney, $\mathrm{z}=-3.77, \mathrm{p}=0.0002$ ) and Frisby stereoacuity (Mann-Whitney, $\mathrm{z}=-2.32, \mathrm{p}=0.02$ ). There was no significant difference in fusional reserves between groups (Mann-Whitney, $p>0.59$ for both analyses).

\section{Table 3 about here}

\section{Discussion}

This is the first study to describe the presence of a clinically significant lag of accommodation in individuals with autism spectrum disorder, with almost one in five children with autism spectrum disorder noted to have a clinically significant lag with their habitual refractive corrections. The autism spectrum disorder group demonstrated a significantly flatter accommodative response profile compared with control participants (Figure 3), also indicating poorer accommodative performance in the autism spectrum disorder group. This relatively poorer performance was evident across the autism spectrum; no difference was detected between those with autism or Asperger's syndrome or across educational categories. It is important to note, when reporting on accommodative performance, that a number of participants in both control and autism spectrum disorder groups had un- or under-corrected presenting refractive error. However, there was no 
significant difference in the magnitude of presenting refractive errors between the control and autism spectrum disorder groups, and such errors cannot explain the accommodative underperformance measured in the autism spectrum disorder group. Furthermore, analysis excluding those with $>/=+2.00 \mathrm{D}$ residual spherical equivalent refractive error still demonstrated significantly more participants with autism spectrum disorder with an accommodative lag compared to the control group.

In this study it was noted that individuals with autism spectrum disorder and a significant lag of accommodation had reduced near visual acuity compared to those with good accommodation. This relationship remained even when those with residual refractive errors (difference of spherical equivalent refractive error $>/=2.00 \mathrm{DS}$ between cycloplegic and habitual refractive state) and those with un- or under-corrected astigmatism (>1.00DC) were excluded from analysis. Our group has previously reported equality in distance visual acuity in autism spectrum disorder compared to typically developing peers, ${ }^{15}$ suggesting that either poor accommodative performance is impacting on near clarity and/or that impaired near vision is reducing the quality of the blur cue which is an important component of accurate accommodation. ${ }^{32,33}$ Another important component of the accommodative response is that driven by convergence. In line with Milne et al., ${ }^{14}$ we note a slight reduction in near point of convergence between autism spectrum disorder and control groups. Previous work by this research group has identified that children with Down syndrome, who are known to have a high prevalence of accommodative dysfunction, demonstrate accurate vergence eye movements despite poor accommodation under binocular conditions. ${ }^{34}$

Accommodation occurs as a reflex response to a variety or combination of visual cues; retinal disparity, retinal blur and target proximity. These cues instigate a physical response in the visual system, resulting in a change in shape of the crystalline lens, contraction or dilation of the pupil and a realignment of the ocular axes. When vision changes focus from distance to near, the crystalline lens becomes more convex as the ciliary muscles contract, the pupil 
sphincter muscle constricts decreasing the pupillary aperture and the right and left eyes converge through the action of the extraocular muscles. Neural control of the ciliary body, pupillary sphincter muscle and the muscles responsible for convergence eye movements originate in the midbrain at the level of the superior colliculus where the Edinger-Westphal nucleus and oculomotor nucleus are situated. Studies examining the neuroanatomy of individuals with autism spectrum disorder have conducted post-mortem examinations of neural structures, ${ }^{3}$ investigated brain volume $e^{35,36}$ and explored the impact of teratogens on the developing embryonic brain. ${ }^{37}$ One such study by Rodier et al.${ }^{37}$ noted a significant reduction of oculomotor nuclei in rodent embryos exposed to a teratogen which caused autism-like deficits. As innervation of the ciliary body from the Edinger Westphal is required for accommodation it may be hypothesised that neurological changes in the brainstem in autism spectrum disorder could result in reduced accommodative accuracy. Recent work has also noted that individuals with autism spectrum disorder have a dysregulated tonic pupil size compared with typically developing individuals. ${ }^{38,39}$ leading to the suggestion of neurological changes in the autonomic system in autism spectrum disorder. ${ }^{38}$ When investigating the potential aetiology for reduced accommodative accuracy in children with cerebral palsy with severe intellectual and physical disabilities damage to the cerebellum or basal ganglia were hypothesised as the potential site of damage resulting in this finding. ${ }^{22,18}$ These structures have also been implicated in the neural basis of autism. ${ }^{40,41}$ It is presently unclear why autism spectrum disorder impacts on accommodative performance, whether hypoaccommodation responds to treatment or whether information about accommodative function could inform our understanding of the neural basis for autistic traits. Further careful investigation of accommodative function, the near triad and the value placed by the autism spectrum disorder visual system on the cues involved in producing an accurate accommodative response is needed. 
Whilst the present study provides valuable avenues for further research into visual function in autism spectrum disorder the findings are also important for eye care clinicians. Unrecognised and untreated reduced near visual function in autism spectrum disorder could impact on educational attainment. It has previously been reported that reduced accommodation may impact on educational achievement ${ }^{42,43}$ and that following correction of accommodative lag using a bifocal addition improved educational attainment was noted in individuals with Down Syndrome. ${ }^{44,45}$ Therefore critical assessment of accommodative accuracy, refractive error and near visual acuity should be undertaken in individuals with autism spectrum disorder to identify deficits and instigate appropriate management.

A significant limitation of the study is that accommodative function and near visual acuity were measured with habitual correction, rather than after full correction of refractive error, hence reflecting a presenting accommodative response and presenting near visual acuity. However, residual refractive errors were considered and shown to have a similar profile in the autism spectrum disorder and control groups. Furthermore, when larger, uncorrected errors were removed from analyses, the finding of poorer accommodative performance and reduced near visual acuity in the autism spectrum disorder group was unchanged. While future studies could investigate whether the deficits we found persist when all refractive errors are fully corrected, the present study presents a useful and novel profile of typical presenting accommodative responses and near visual functions for a large population-based sample of those with autism spectrum disorder and an age-matched control group.

Refractive errors were measured after cycloplegia in the present study. It is possible that full cycloplegia was not elicited in every participant. Effort was made to ensure that cycloplegia was effective using a standard protocol of a 30-minute delay after instillation of $1 \%$ cyclopentolate and this, coupled with examination of pupil size and response, has been deemed sufficient in other studies in our Caucasian population. ${ }^{27}$ 
In summary, presenting accommodative response was significantly poorer amongst individuals with autism spectrum disorder. Individuals with autism spectrum disorder were over 3.7 times more likely to have a clinically significant lag of accommodation compared to the control group. In addition, we found subtle reductions in presenting near visual acuity and convergence in the autism spectrum disorder group. These findings raise a number of interesting research questions relating to near visual processing in autism spectrum disorder. They also highlight a need for eye care clinicians to be aware of and pro-active in assessment and managing refractive error and near visual functions in patients with autism spectrum disorder.

\section{Acknowledgements}

This work was supported by the Northern Ireland Health \& Social Care Research \& Development for Northern Ireland (EAT/4197/09). We would like to thank Dr Khan for assistance with recruitment, Dr Sara McCullough and Dr Lesley Doyle for assistance with data collection and Mrs Clare Stevenson and Mrs Joy Peters for providing test facilities. We are grateful to all participants and schools who consented to involvement in the study including Bangor Central Primary School, Belmont House, Castle Gardens Primary School, Foyleview School, Knockavoe School, Londonderry Primary School, Loreto College, Strangford College and Victoria Primary School in Northern Ireland, UK. This work formed part of a doctoral thesis by the lead author and was previously presented in part at the Association for Research in Vision and Ophthalmology Meeting (Florida, USA, 2014) and the International Orthoptic Association conference (Rotterdam, Netherlands, 2016). 


\section{References}

1 Bertrand J, Mars A, Boyle C, et al. Prevalence of Autism in a United States Population: The Brick Township, New Jersey, Investigation. Pediatr 2001;108:1155-61.

2 Dover CJ, Le Coteur A. How to Diagnose Autism. Arch Dis Child 2007;92:540-45.

3 Bailey A, Luthert P, Dean A, et al. A Clinicopathological Study of Autism. Brain 1998;121:889-905.

4 Christensen DL, Baio J, van Naarden Braun, et al. Prevalence and Characteristics of Autism Spectrum Disorder Among Children Aged 8 Years - Autism and Developmental Disabilities Monitoring Network, 11 sites, United States, 2012. MMWR Surveill Summ 2016;165:1-23

5 Milne E, Swettenham J, Hansen P, et al. High Motion Coherence Thresholds in Children with Autism. J Child Psychol Psych 2002;43:255-63.

6 Takarae Y, Minshew NJ, Luna B, Krisky CM, Sweeney JA. Pursuit Eye Movement Deficits in Autism. Brain 2004;127:2584-94.

7 Kemner C, Van der Geest JN, Verbaten MN, van Engeland H. In Search of Neurophysiological Markers of Pervasive Developmental Disorders: Smooth Pursuit Eye Movements? J Neural Trans 2004;111:1617-26.

8 Falkmer M, Stuart GW, Danielsson H, et al. Visual Acuity in Adults with Asperger's Syndrome: No evidence for Eagle-Eyed Vision. Biol Psych 2011;70:812-16.

9 Ashwin E, Ashwin C, Rhydderch D, et al. Eagle-Eyed Visual Acuity: an Experimental Investigation of Enhanced Perception in Autism. Biol Psych 2009;1;65:17-21.

10 Bölte S, Schlitt S, Gapp V, et al. A Close Eye on the Eagle-Eyed Visual Acuity Hypothesis of Autism. J Autism Dev Disorder 2012;42:726-33. 
11 Kaplan M, Rimland B, Edelson SM. Strabismus in Autistic Spectrum Disorder. Focus Autism Other Dev Disabl 1999;14;2:101-5.

12 Scharre JE, Creedon MP. Assessment of Visual Function in Autistic Children. Optom Vis Sci 1992;69;6:433-9.

13 Ikeda J, Davitt BV, Ultmann M, et al. Brief Report: Incidence of Ophthalmologic Disorders in Children with Autism. J Autism Dev Dis 2013;43;6:1447-51.

14 Milne E, Griffiths H, Buckley D, et al. Vision in Children and Adolescents with Autistic Spectrum Disorder: Evidence For Reduced Convergence. J Autism Dev Dis 2009;39:965-75.

15 Anketell PM, Saunders KJ, Gallagher SM, et al. Brief Report: Vision in Children with Autism Spectrum Disorder: What Should Clinicians Expect? J Autism Dev Dis 2015;45;9:3041-47.

16 Kulp MT, Ciner E, Maguire M, et al. VIP-HIP Study Group. Uncorrected Hyperopia and Preschool Early Literacy: Results of the Vision in Preschoolers-Hyperopia in Preschoolers (VIP-HIP) Study. Ophthalmology. 2016;123:681-9.

17 Woodhouse JM, Meades JS, Leat SJ, et al. Reduced Accommodation in Children with Down Syndrome. Invest Ophthalmol Vis Sci 1993;34;7:2382-87.

18 McClelland JF, Parkes J, Hill N, et al. Accommodative Dysfunction in Children with Cerebral Palsy: A Population-Based Study. Invest Ophthalmol Vis Sci 2006;47;5:1824-30.

19 Leat SJ, Gargon JL. Accommodative Response in Children and Young Adults Using Dynamic Retinoscopy. Ophthalmic Physliol Opt 1996;16;5:375-84.

20 McClelland JF, Saunders KJ. The Repeatability and Validity of Dynamic Retinoscopy in Assessing the Accommodative Response. Ophthalmic Physiol Opt 2003;23:243-50. 
21 Antona, B, Sanchez I, Barrio A et al. Intra-Examiner Repeatability and Agreement in Accommodative Response Measurements. Ophthalmic Physiol Opt 2009;29:1-9.

22 Leat SJ. Reduced Accommodation in Children with Cerebral Palsy. Ophthalmic Physiol Opt 1996;16;5:385-9.0

23 McClelland JF, Saunders KJ. Accommodative Lag using Dynamic Retinoscopy: Age Norms for School-Age Children. Optom Vis Sci 2004;81;12:929-33.

24 Rouse MW, Hutter RF. A Normative Study of the Accommodative Lag in Elementary School Children. Am J Optom Physiol Opt 1984;61:669-93.

25 Cregg M, Woodhouse JM, Pakeman VH, et al. Accommodation and Refractive Error in Children with Down Syndrome: Cross Sectional and Longitudinal Studies. Invest Ophthalmol Vis Sci 2001;42:55-63.

26 Anketell PM, Saunders KJ, Little J-A. Stereoacuity Norms for School-Aged Children Using the Frisby Stereotest. JAAPOS 2013;17;6:582-87.

27 O'Donoghue L, Saunders KJ, McClelland JF et al Sampling and Measurement Methods for a Study of Childhood Refractive Error in a UK Population. Br J Ophthalmol 2010; 94:1150-1154.

28 Anketell PM, Saunders KJ, Gallagher S et al. Profile of Refractive Errors in European Caucasian Children with Autistic Spectrum Disorder; Increased Prevalence and Magnitude of Astigmatism. Ophthalmic Physiol Opt. 2016;36:395-403.

29 McCullough SJ, Doyle L, Saunders KJ. Intra- and Inter- Examiner Repeatability of Cycloplegic Retinoscopy Among Young Children. Ophthalmic Physiol Opt. 2017;37:16-23.

30 Leat SJ. To Prescribe or Not To Prescribe? Guidelines for Spectacle Prescribing in Infants and Children. Clin Exp Optom. 2011;94:514-27. 
31 Mutti DO. To Emmetropize or Not To Emmetropize? The Question for Hyperopic Development. Optom Vis Sci. 2007;84:97-102.

32 Bharadwaj SR, Candy TR. Cues for the Control of Ocular Accommodation and Vergences During Postnatal Human Development. J Vis 2008;8;16;14:1-16.

33 Horwood AM, Riddell PM. The Use of Cues to Convergence and Accommodation in Naïve, Uninstructed Participants. Vision Res 2008;48:1613-24.

34 Doyle LA, Saunders KJ, Little JA. Trying to See, Failing to Focus: Near Visual Impairment in Down Syndrome. Sci Rep 2016;5;6:20444

35 Courchesne E, Carper R, Akshoomoff N. Evidence of Brain Overgrowth in the First Year of Life. JAMA 2003;290:337-44.

36 Aylward EH, Minshew NJ, Field K, et al. The Effects of Age on Brain Volume and Head Circumference. Neurology 2002;59:175-83.

37 Rodier PM, Ingram JL, Tisdale B, et al. Embryological Origin for Autism: Developmental Anomalies of the Cranial Nerve Motor Nuclei. J Comp Neurol 1996;370:247-61.

38 Anderson CJ, Colombo J. Larger Tonic Pupil Size in Young Children with Autism Spectrum Disorder. Dev Psychobiol 2009;51:2:207-11.

39 Nyström P, Gredebäck G, Bölte S, et al. Hypersensitive Pupillary Light Reflex in Infants at Risk For Autism. Mol Autism 2015;6:10-5.

40 Amaral DG, Schumann CM, Nordahl CW. Neuroanatomy of Autism. Trends Neurosci 2008;31;3:137-45.

41 Rogers TD, McKimm E, Dickson PE, et al. Is Autism a Disease of the Cerebellum? An Integration of Clinical and Pre-Clinical Research. Front Neurosci 2013;10;7:15. 
42 Dusek W, Pierscionek BP, McClelland JF. A Survey of Visual Function in an Austrian Population of School-Aged Children with Reading and Writing Difficulties. BMC Ophthalmol 2010;10:16-25.

43 Narayanasamy S, Vincent SJ, Sampson GP et al. Impact of Simulated Hyperopia on Academic-Related Performance in Children. Optom Vis Sci 2015;92;2:227-36.

44 Nandakumar K, Leat SJ. Bifocals in Down Syndrome (BiDS): Design and Baseline Function. OptomVis Sci 2010;86;3:196-207.

45 Nandakumar K, Leat SJ. Bifocals in Down Syndrome (BiDS) - visual acuity, accommodation and early literacy skills. Acta Ophthalmol 2010;88:e196-204. 


\section{Figure legends}

Figure 1 illustrates a participant fixing on the UC cube for assessment of accommodation by the modified Nott dynamic retinoscopy technique.

Figure 2 illustrates the individual habitual mean spherical equivalent refractive correction against the cycloplegic spherical equivalent refractive error (SER) for the autism spectrum disorder (ASD) (black hollow triangles) and control participants (black crosses). No habitual spectacle prescription was defined as 0.00D SER. The dashed and dotted lines represent linear regressions of the ASD $\left(\mathrm{R}^{2}=0.73, \mathrm{y}=1.2 \mathrm{x}+1.00\right)$ and control data $\left(\mathrm{R}^{2}=0.64, \mathrm{y}=1.11 \mathrm{x}\right.$ +1.10 ) respectively.

Figure 3 illustrates the individual accommodative demand against the accommodative response for the autism spectrum disorder (ASD) (black hollow triangles) and control participants (black crosses). The dashed and dotted lines represent linear regressions of the ASD $\left(y=0.82 x+0.29, R^{2}=0.69\right)$ and control $\left(y=0.97 x-0.17, R^{2}=0.77\right)$ data respectively. The short-dashed gray line represents the lower limit of accommodative response for typically developing children. ${ }^{23}$ 


\section{Table 1}

Table 1; Median SER, sphere and cylinder (interquartile range (IQR)) for cycloplegic autorefraction for the ASD and control groups.

\begin{tabular}{|c|c|c|}
\hline Cycloplegic Refractive error & $\begin{array}{l}\text { ASD group } \\
(\mathrm{n}=109)\end{array}$ & $\begin{array}{l}\text { Control group } \\
(n=202)\end{array}$ \\
\hline Median SER, D, (IQR) & $\begin{array}{l}+1.00 \mathrm{D} \\
\text { (IQR: }+0.375 \text { to } \\
+1.50) \\
\text { Range }-4.125 \text { to }+9.50\end{array}$ & $\begin{array}{l}+1.125 \mathrm{D} \\
(\mathrm{IQR}:+0.50 \text { to }+1.625) \\
\text { Range }-6.125 \text { to }+6.75\end{array}$ \\
\hline Median Sphere, D, (IQR) & $\begin{array}{l}+1.25 \mathrm{D} \\
(+0.50 \text { to }+2.00) \\
\text { Range }-3.75 \text { to }+10.50\end{array}$ & $\begin{array}{l}+1.25 \mathrm{D} \\
(\mathrm{IQR}:+0.75 \text { to }+1.75) \\
\text { Range }-5.50 \text { to }+7.00\end{array}$ \\
\hline "Median Cylinder, D, (IQR) & $\begin{array}{l}-0.50 \mathrm{D} \\
(-0.75 \text { to }-0.50) \\
\text { Range }-3.25 \text { to } 0.00\end{array}$ & $\begin{array}{l}-0.50 \mathrm{D} \\
(-0.50 \text { to }-0.25) \\
\text { Range }-2.25 \text { to } 0.00\end{array}$ \\
\hline
\end{tabular}

Key to abbreviations: SER=Spherical equivalent refractive error, D=Diopters, ASD=Autism spectrum disorder, $\mathrm{IQR}=$ Inter-quartile range 


\section{Table 2}

Table 2; Median, interquartile range (IQR) and statistical analyses for lag of accommodation, accommodative response and accommodative demand the autism spectrum disorder (ASD) and control groups. Data is also given for the ASD group by educational classification.

\begin{tabular}{|c|c|c|c|c|c|}
\hline $\begin{array}{l}\text { Accommodative } \\
\text { function }\end{array}$ & \multicolumn{3}{|l|}{$\begin{array}{l}\text { ASD group } \\
(n=109)\end{array}$} & $\begin{array}{l}\text { Control group } \\
(n=202)\end{array}$ & $\begin{array}{l}\text { Statistical } \\
\text { analyses }\end{array}$ \\
\hline \multirow[t]{2}{*}{$\begin{array}{l}\text { Median lag, D, } \\
\text { (IQR) }\end{array}$} & \multicolumn{3}{|c|}{$\begin{array}{l}0.43 \mathrm{D} \\
\text { (IQR: } 0.00 \text { to } 0.88) \\
\text { (Range: } 0.00 \mathrm{D} \text { to } 2.25 \mathrm{D} \text { ) }\end{array}$} & \multirow[t]{2}{*}{$\begin{array}{l}0.00 \mathrm{D} \\
\text { (IQR: } 0.00 \text { to } \\
0.55 \text { ) } \\
\text { (Range -1.88D } \\
\text { to 1.92D) }\end{array}$} & \multirow[t]{2}{*}{$\begin{array}{l}\mathrm{MW}=-3.50, \\
p=0.0005\end{array}$} \\
\hline & $\begin{array}{l}\text { Mainstream no } \\
\text { SEN } \\
0.36 \mathrm{D} \\
(0.00 \text { to } 0.67)\end{array}$ & \begin{tabular}{|l|}
$\begin{array}{l}\text { Mainstream } \\
\text { with SEN }\end{array}$ \\
$0.15 \mathrm{D}$ \\
$(0.00$ to 0.77$)$
\end{tabular} & \begin{tabular}{|l|}
$\begin{array}{l}\text { Special } \\
\text { Education }\end{array}$ \\
$0.66 \mathrm{D}$ \\
$(0.00$ to 1.14$)$
\end{tabular} & & \\
\hline \multirow{2}{*}{$\begin{array}{l}\text { Median } \\
\text { Accommodative } \\
\text { Response, D, } \\
\text { (IQR) }\end{array}$} & \multicolumn{3}{|l|}{$\begin{array}{l}4.25 \mathrm{D} \\
(3.57 \text { to } 4.82)\end{array}$} & \multirow[t]{2}{*}{$\begin{array}{l}4.57 \mathrm{D} \\
(4.03 \text { to } 5.25)\end{array}$} & \multirow[t]{2}{*}{$\begin{array}{l}\text { MW=3.48, } \\
p=0.0005\end{array}$} \\
\hline & $\begin{array}{l}\begin{array}{l}\text { Mainstream } \\
\text { no SEN }\end{array} \\
4.29 \mathrm{D} \\
\text { (3.73 to 4.79) }\end{array}$ & $\begin{array}{l}\begin{array}{l}\text { Mainstream } \\
\text { with SEN }\end{array} \\
4.19 \mathrm{D} \\
(3.50 \text { to } 4.70)\end{array}$ & \begin{tabular}{|l|}
$\begin{array}{l}\text { Special } \\
\text { Education }\end{array}$ \\
$4.11 \mathrm{D}$ \\
(3.50 to 5.00 )
\end{tabular} & & \\
\hline \multirow{2}{*}{$\begin{array}{l}\text { Median } \\
\text { Accommodative } \\
\text { Demand, D, } \\
\text { (IQR) }\end{array}$} & \multicolumn{3}{|l|}{$\begin{array}{l}4.75 \mathrm{D} \\
\text { (4.25 to } 5.25 \text { ) }\end{array}$} & \multirow[t]{2}{*}{$\begin{array}{l}5.00 \mathrm{D} \\
\text { (4.50 to } 5.25)\end{array}$} & \multirow[t]{2}{*}{$\begin{array}{l}\text { MW=2.35, } \\
p=0.019\end{array}$} \\
\hline & $\begin{array}{l}\begin{array}{l}\text { Mainstream } \\
\text { no SEN }\end{array} \\
4.63 \mathrm{D} \\
\text { (4.25 to } 5.13)\end{array}$ & $\begin{array}{l}\text { Mainstream } \\
\text { with SEN } \\
4.50 \mathrm{D} \\
(4.25 \text { to } 5.00)\end{array}$ & \begin{tabular}{|l|}
$\begin{array}{l}\text { Special } \\
\text { Education }\end{array}$ \\
$4.75 \mathrm{D}$ \\
$(4.25$ to 5.50$)$
\end{tabular} & & \\
\hline
\end{tabular}

Key to abbreviations: $\mathrm{D}=$ Diopters, $\mathrm{ASD}=$ Autism spectrum disorder, IQR=Inter-quartile range, SEN=Special educational needs support, MW=Mann-Whitney 


\section{Table 3}

Table 3; descriptive statistics for near visual acuity, near point of convergence, spherical equivalent refractive error, fusional reserves and reduced stereoacuity for participants with and without a clinically significant lag of accommodation in the control and autism spectrum disorder (ASD) groups. Statistical analyses are described for both the ASD and control groups for comparison those individuals with and without a significant lag of accommodation.

\begin{tabular}{|c|c|c|c|c|c|c|c|c|}
\hline \multirow[b]{2}{*}{ Group } & \multirow{2}{*}{$\begin{array}{l}\text { ASD } \\
\text { group }\end{array}$} & \multirow{2}{*}{$\begin{array}{l}\text { Contr } \\
\text { ol } \\
\text { group }\end{array}$} & \multicolumn{3}{|l|}{ ASD group } & \multicolumn{3}{|c|}{ Control group } \\
\hline & & & $\begin{array}{l}\text { With a lag } \\
\text { of } \\
\text { accommod } \\
\text { ation }\end{array}$ & $\begin{array}{l}\text { Without a } \\
\text { lag of } \\
\text { accommoda } \\
\text { tion }\end{array}$ & $\begin{array}{l}\text { Statistic } \\
\text { al } \\
\text { analyses }\end{array}$ & $\begin{array}{l}\text { With a lag } \\
\text { of } \\
\text { accommoda } \\
\text { tion }\end{array}$ & $\begin{array}{l}\text { Without a } \\
\text { lag of } \\
\text { accommod } \\
\text { ation }\end{array}$ & $\begin{array}{l}\text { Statistical } \\
\text { analyses }\end{array}$ \\
\hline \multirow{6}{*}{$\begin{array}{l}\text { Median NVA, } \\
\text { logMAR, } \\
\text { (IQR) } \\
\text { (ASD n=94, } \\
\text { Controls } \\
n=202 \text { ) }\end{array}$} & \multirow[t]{5}{*}{$\begin{array}{l}-0.06 \\
(-0.12 \\
\text { to } \\
0.00)\end{array}$} & \multirow[t]{5}{*}{$\begin{array}{l}-0.097 \\
(-0.14 \\
\text { to } \\
0.00)\end{array}$} & $\begin{array}{l}0.00 \\
(0.00 \text { to } \\
0.10)\end{array}$ & $\begin{array}{l}-0.06 \\
(-0.14 \text { to } \\
0.00)\end{array}$ & $\begin{array}{l}M W=- \\
2.46, \\
p=0.01\end{array}$ & $\begin{array}{l}-0.09 \\
(-0.14 \text { to } \\
0.02)\end{array}$ & $\begin{array}{l}-0.10 \\
(-0.14 \text { to } \\
0.00)\end{array}$ & $\begin{array}{l}\mathrm{MW}=- \\
0.12, \\
p=0.90\end{array}$ \\
\hline & & & \multicolumn{6}{|c|}{$\begin{array}{l}\text { Excluding participants with residual SER }>/=2.00 D S \text { (Remaining } n: \text { ASD } \\
\qquad n=85 \text {, Controls } n=178 \text { ) }\end{array}$} \\
\hline & & & $\begin{array}{l}0.00 \\
(0.00 \text { to } \\
0.10)\end{array}$ & $\begin{array}{l}-0.07 \\
(-0.16 \text { to } \\
0.00)\end{array}$ & $\begin{array}{l}M W=- \\
2.83 \\
p=0.005\end{array}$ & $\begin{array}{l}-0.04 \\
(-0.14 \text { to } \\
0.02)\end{array}$ & $\begin{array}{l}-0.10 \\
(-0.14 \text { to }- \\
0.02)\end{array}$ & $\begin{array}{l}\mathrm{MW}=- \\
0.47 \\
p=0.64\end{array}$ \\
\hline & & & \multicolumn{6}{|c|}{$\begin{array}{l}\text { Excluding participants with residual SER>/=2.00DS and }>1.00 D C \text { excluded } \\
\text { (Remaining } n: A S D n=79 \text {, Controls } n=176 \text { ) }\end{array}$} \\
\hline & & & \multirow{2}{*}{$\begin{array}{l}0.00 \\
(0.00 \text { to } \\
0.15)\end{array}$} & \multirow{2}{*}{$\begin{array}{l}-0.07 \\
(-0.15 \text { to } \\
0.00)\end{array}$} & \multirow{2}{*}{$\begin{array}{l}M W=- \\
2.08, \\
p=0.03\end{array}$} & \multirow{2}{*}{$\begin{array}{l}-0.04 \\
(-0.14 \text { to } \\
0.02)\end{array}$} & \multirow{2}{*}{$\begin{array}{l}-0.10 \\
(-0.14 \text { to - } \\
0.02)\end{array}$} & \multirow{2}{*}{$\begin{array}{l}\mathrm{MW}=- \\
0.47 \\
p=0.64\end{array}$} \\
\hline & $\begin{array}{l}\mathrm{MW}=- \\
p=0.18\end{array}$ & & & & & & & \\
\hline \multirow{5}{*}{$\begin{array}{l}\text { *Median } \\
\text { NPC, cm, } \\
(I Q R) \\
(\text { ASD n=100, } \\
\text { Controls } \\
n=199)\end{array}$} & \multirow[t]{5}{*}{$\begin{array}{l}5.7 \\
(5.0 \text { to } \\
8.0)\end{array}$} & \multirow[t]{5}{*}{$\begin{array}{l}5.0 \\
(5.0 \text { to } \\
6.0)\end{array}$} & $\begin{array}{l}6.7 \\
(6.0 \text { to } 9.3)\end{array}$ & $\begin{array}{l}5.3 \\
(5.0 \text { to } 8.0)\end{array}$ & $\begin{array}{l}M W=- \\
2.09, \\
p=0.037\end{array}$ & $\begin{array}{l}5.0 \\
(5.0 \text { to } 7.7)\end{array}$ & $\begin{array}{l}5.0 \\
(5.0 \text { to } 6.0)\end{array}$ & $\begin{array}{l}\text { MW=- } \\
0.29 \\
p=0.77\end{array}$ \\
\hline & & & \multicolumn{6}{|c|}{$\begin{array}{l}\text { Excluding participants with residual SER }>/=2.00 D S \text { excluded (Remaining } n: \\
\qquad A S D n=89 \text {, Controls } n=176 \text { ) }\end{array}$} \\
\hline & & & $\begin{array}{l}6.7 \\
(6.0 \text { to } 8.0)\end{array}$ & $\begin{array}{l}5.3 \\
(5.0 \text { to } 8.0)\end{array}$ & $\begin{array}{l}M W=- \\
2.10 \\
p=0.036\end{array}$ & $\begin{array}{l}5.0 \\
(5.0 \text { to } 9.2)\end{array}$ & $\begin{array}{l}5.0 \\
(5.0 \text { to } 6.0)\end{array}$ & $\begin{array}{l}\mathrm{MW}=- \\
0.55 \\
p=0.58\end{array}$ \\
\hline & & & \multicolumn{6}{|c|}{$\begin{array}{l}\text { Excluding participants with residual SER>/=2.00DS and }>1.00 D C \text { excluded } \\
\text { (Remaining } n: A S D n=83 \text {, Controls } n=174 \text { ) }\end{array}$} \\
\hline & & & $\begin{array}{l}6.7 \\
\text { (6.0 to } 7.3 \text { ) }\end{array}$ & $\begin{array}{l}5.3 \\
(5.0 \text { to } 8.7)\end{array}$ & $\begin{array}{l}M W=- \\
1.57 \\
p=0.12\end{array}$ & $\begin{array}{l}5.0 \\
(5.0 \text { to } 9.2)\end{array}$ & $\begin{array}{l}5.0 \\
(5.0 \text { to } 6.0)\end{array}$ & $\begin{array}{l}\text { MW=- } \\
0.55 \\
p=0.58\end{array}$ \\
\hline
\end{tabular}




\begin{tabular}{|c|c|c|c|c|c|c|c|c|}
\hline \multirow{3}{*}{\begin{tabular}{|l|} 
\\
Median SER, \\
D, (IQR) \\
\\
(ASD n=109, \\
Controls \\
n=202)
\end{tabular}} & \multicolumn{2}{|c|}{$p<0.0001$} & & & & & & \\
\hline & $\begin{array}{l}+1.00 \\
(+0.3 \\
8 \text { to } \\
+1.50 \\
)\end{array}$ & $\begin{array}{l}+1.13 \\
(+0.5 \\
0 \text { to } \\
+1.63 \\
)\end{array}$ & \multirow[t]{2}{*}{$\begin{array}{l}+1.25 \\
(+0.38 \text { to } \\
+4.25)\end{array}$} & \multirow[t]{2}{*}{$\begin{array}{l}+0.88 \\
(+0.25 \text { to } \\
+1.50)\end{array}$} & \multirow[t]{2}{*}{$\begin{array}{l}\text { MW=- } \\
2.00, \\
p=0.05\end{array}$} & \multirow[t]{2}{*}{$\begin{array}{l}+0.69 \\
(+0.00 \text { to } \\
+1.00)\end{array}$} & \multirow[t]{2}{*}{$\begin{array}{l}+1.13 \\
(+0.50 \text { to } \\
+1.63)\end{array}$} & \multirow[t]{2}{*}{$\begin{array}{l}\mathrm{MW}=1.1 \\
9, p=0.24\end{array}$} \\
\hline & \multicolumn{2}{|c|}{$\begin{array}{l}\mathrm{MW}=1.34 \\
p=0.18\end{array}$} & & & & & & \\
\hline \multirow[t]{2}{*}{$\begin{array}{l}\text { Median } \\
\text { cylinder, DC, } \\
\text { (IQR) (ASD } \\
\text { n=109, } \\
\text { Controls } \\
\text { n=202) }\end{array}$} & $\begin{array}{l}-0.50 \\
\\
(-0.75 \\
\text { to - } \\
0.50)\end{array}$ & $\begin{array}{l}-0.50 \\
(-0.50 \\
\text { to - } \\
0.25)\end{array}$ & \multirow[t]{2}{*}{$\begin{array}{l}-0.75 \\
(-1.75 \text { to }- \\
0.38)\end{array}$} & \multirow[t]{2}{*}{$\begin{array}{l}-0.50 \\
(-0.75 \text { to }- \\
0.50)\end{array}$} & \multirow[t]{2}{*}{$\begin{array}{l}\text { MW=1. } \\
94, \\
p=0.05\end{array}$} & \multirow[t]{2}{*}{$\begin{array}{l}-0.25 \\
(-0.50 \text { to } \\
0.00)\end{array}$} & \multirow[t]{2}{*}{$\begin{array}{l}-0.50 \\
(-0.50 \text { to - } \\
0.25)\end{array}$} & \multirow[t]{2}{*}{$\begin{array}{l}\text { MW=- } \\
0.69, \\
p=0.49\end{array}$} \\
\hline & \multicolumn{2}{|c|}{$\begin{array}{l}\text { MW = 4.03, } \\
p=0.0001\end{array}$} & & & & & & \\
\hline \multirow{2}{*}{$\begin{array}{l}\text { *Base Out } \\
\text { Fusional } \\
\text { Reserve, } \\
\text { Prism } \\
\text { Dioptres, } \\
\text { (IQR) } \\
\text { (ASD n=73, } \\
\text { Controls } \\
\text { n=199) }\end{array}$} & $\begin{array}{l}20 \\
\text { (16 to } \\
35)\end{array}$ & $\begin{array}{l}20 \\
\text { (14 to } \\
35)\end{array}$ & \multirow[t]{2}{*}{$\begin{array}{l}18 \\
\text { (12 to } 25)\end{array}$} & \multirow[t]{2}{*}{$\begin{array}{l}22.5 \\
\text { (16 to } 35 \text { ) }\end{array}$} & \multirow[t]{2}{*}{$\begin{array}{l}\text { MW }=0 . \\
67, \\
p=0.50\end{array}$} & \multirow[t]{2}{*}{$\begin{array}{l}40 \\
\text { (35 to 40) }\end{array}$} & \multirow[t]{2}{*}{$\begin{array}{l}20 \\
\text { (14 to } 35)\end{array}$} & \multirow[t]{2}{*}{$\begin{array}{l}M W=- \\
3.36, \\
p=0.0008\end{array}$} \\
\hline & \multicolumn{2}{|c|}{$\begin{array}{l}\mathrm{MW}=0.41, \\
p=0.69\end{array}$} & & & & & & \\
\hline \multirow{2}{*}{$\begin{array}{l}\text { *Base In } \\
\text { Fusional } \\
\text { Reserve, } \\
\text { Prism } \\
\text { Dioptres, } \\
\text { (IQR) (ASD } \\
\text { n=73, } \\
\text { Controls } \\
\mathrm{n}=199 \text { ) }\end{array}$} & $\begin{array}{l}12 \\
\text { (8 to } \\
14)\end{array}$ & $\begin{array}{l}10 \\
\text { (8 to } \\
14)\end{array}$ & \multirow[t]{2}{*}{$\begin{array}{l}10 \\
\text { (6 to } 16 \text { ) }\end{array}$} & \multirow[t]{2}{*}{$\begin{array}{l}12 \\
\text { (8 to } 14 \text { ) }\end{array}$} & \multirow[t]{2}{*}{$\begin{array}{l}\mathrm{MW}=0 . \\
58, \\
p=0.56\end{array}$} & \multirow[t]{2}{*}{$\begin{array}{l}12 \\
\text { (10 to } 16)\end{array}$} & \multirow[t]{2}{*}{$\begin{array}{l}10 \\
\text { (8 to } 14 \text { ) }\end{array}$} & \multirow[t]{2}{*}{$\begin{array}{l}\text { MW=- } \\
1.37 \\
p=0.17\end{array}$} \\
\hline & \multicolumn{2}{|c|}{$\begin{array}{l}\mathrm{MW}=-0.53 \\
p=0.59\end{array}$} & & & & & & \\
\hline \multirow{2}{*}{$\begin{array}{l}\text { *Reduced } \\
\text { Stereoacuity } \\
(>85 "), n(\%) \\
\text { (ASD n=96, } \\
\text { Controls } \\
n=199)\end{array}$} & $\begin{array}{l}9 \\
(9.4)\end{array}$ & $\begin{array}{l}5 \\
(2.5)\end{array}$ & \multirow[t]{2}{*}{2} & \multirow[t]{2}{*}{7} & & \multirow[t]{2}{*}{0} & \multirow[t]{2}{*}{5} & \\
\hline & $\begin{array}{l}\mathrm{MW}= \\
p=0.0 \mathrm{c}\end{array}$ & & & & & & & \\
\hline
\end{tabular}

Those analyses with a statistically significant difference are highlighted in bold italics. *Indicates that before statistical analysis of binocular function data individuals with a manifest strabismus were excluded

Key to abbreviations: $\mathrm{D}=$ Diopters, $\mathrm{ASD}=$ Autism spectrum disorder, $\mathrm{IQR}=$ Inter-quartile range, NVA=Near visual acuity, NPC=Near point of convergence, $S E R=$ Spherical equivalent refractive error, MW=Mann-Whitney 


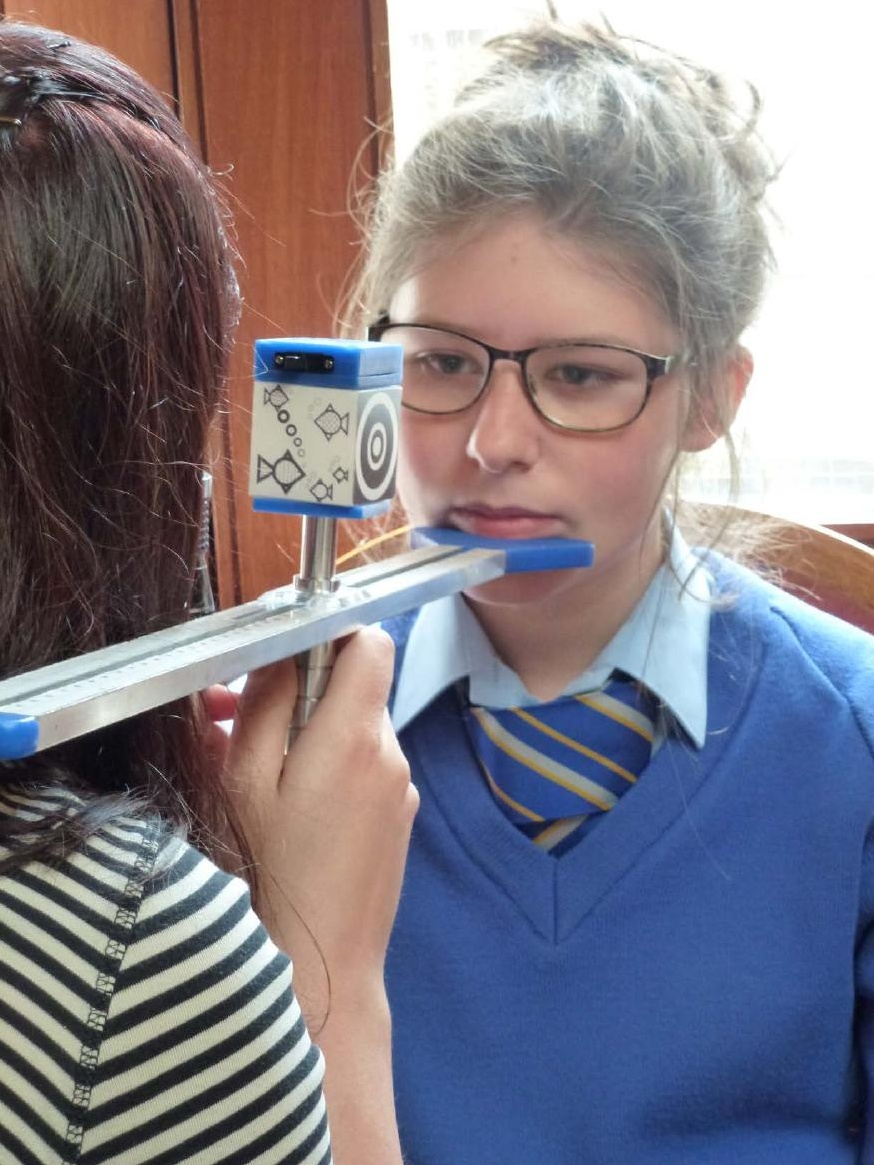




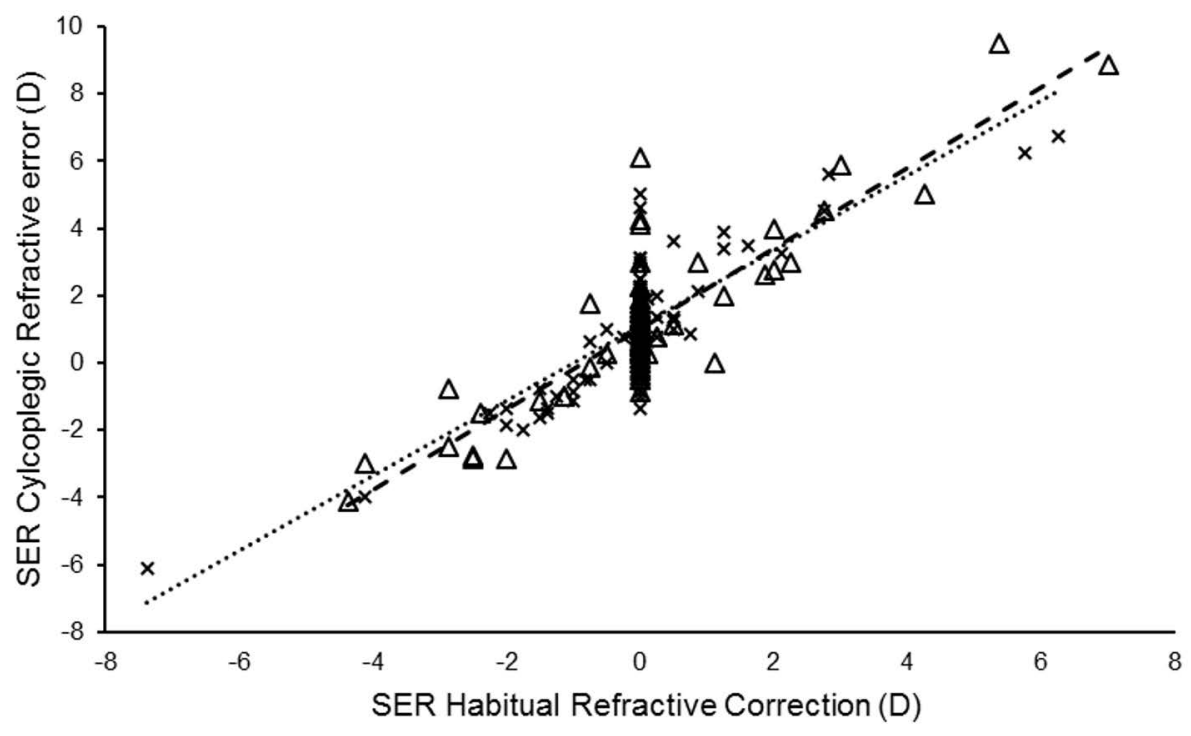




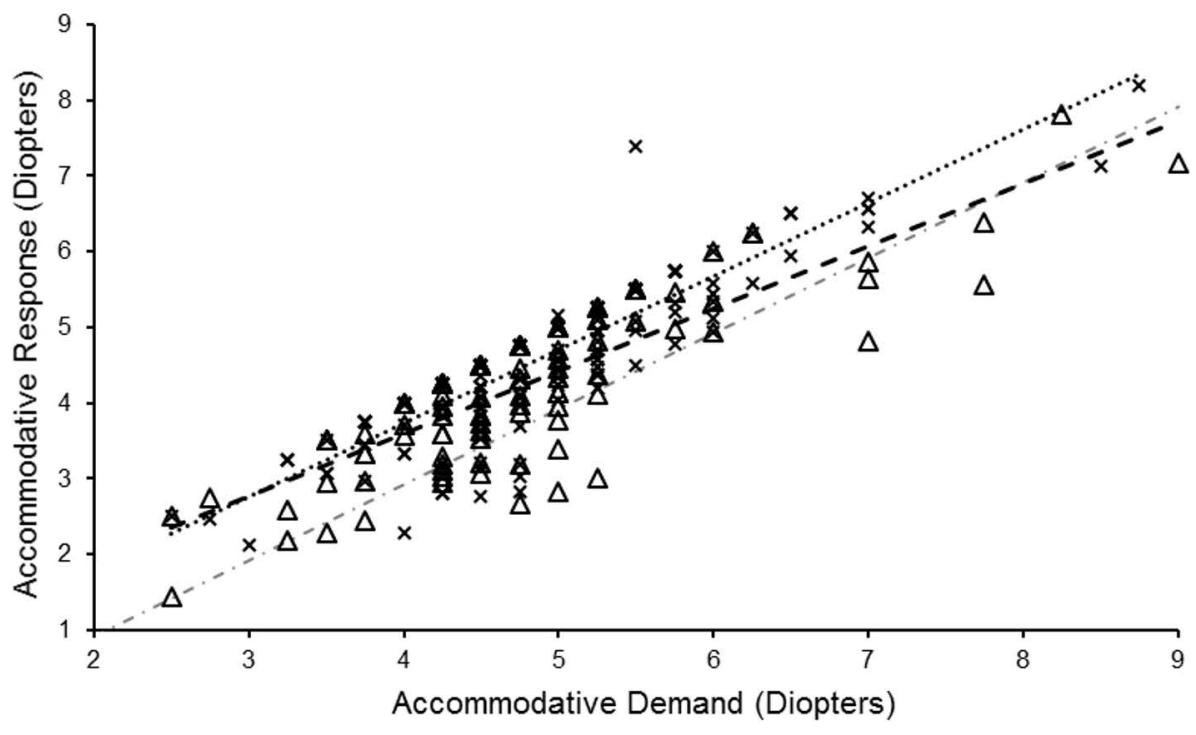

